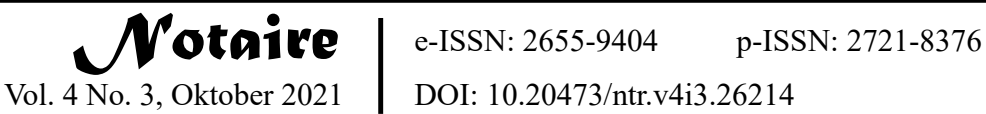

Article history: Submitted 5 April 2021; Accepted 6 June 2021; Available online 1 October 2021.

\title{
Keabsahan dan Akibat Hukum Perkawinan Penghayat Kepercayaan Pasca Terbitnya Putusan Mahkamah Konstitusi Nomor 97/PUU-XIV/2016
}

\author{
Safirah Oktavihana dan Nindia Putri Prameswari \\ safirahoktavihana@gmail.com \\ Universitas Airlangga
}

\begin{abstract}
Marriage is one of the process of human life as regulated in Article 28B paragraph (1) of the 1945 Constitution of the Republic of Indonesia and also regulated in Article 10 of the Human Rights Law. Marriages conducted by Believers are regulated and protected in the Adminduk Law and the implementing Government Regulations, but not accommodated in Law Number 1 of 1974 on Marriage which is the lex specialist of the regulations governing Marriage in Indonesia. This research uses normative legal research method whose main object is the legal substance of legal protection for Believers on the basis of recognition of belief according to the mandate of the 1945 NRI Constitution, due to incomplete norms and exclusive interpretation of the meaning of the words "God Almighty" and "and trust that". This research is expected to provide an understanding to stakeholders regarding the validity of marriages conducted by Believers and provide administrative legal protection to Believer. The Constitutional Court Decision Number 97/PUU-XIV/2016 provides legal solutions and protection for Believers for administrative legal arrangements that have not fully protected the existence of believers in the God Almighty. After the issuance of Constitutional Court's decision, the marriage of Believers was recognized as a legal marriage and brought good legal consequences for their offspring.

Keywords: Legal Protection; Believer; Marriage; Law of Administration.
\end{abstract}

Perkawinan adalah salah satu $\quad$ proses kehidupan manusia yang diatur dalam Pasal 28B ayat (1) UUD NRI Tahun 1945 dan diatur pula dalam Pasal 10 UU HAM. Perkawinan yang dilakukan oleh Penghayat Kepercayaan diatur dan dilindungi dalam UU Adminduk dan Peraturan Pemerintah pelaksananya, namun tidak diakomodir dalam UU Nomor 1 Tahun 1974 tentang Perkawinan yang merupakan lex specialis dari peraturan yang mengatur tentang Perkawinan di Indonesia. Penelitian ini menggunakan metode penelitian hukum normatif yang obyek utamanya adalah substansi hukum atas perlindungan hukum bagi Penghayat Kepercayaan atas dasar pengakuan Kepercayaan sesuai amanat UUD NRI Tahun 1945, akibat kekuranglengkapan norma dan penafsiran eksklusif makna kata "Ketuhanan Yang Maha Esa" dan "dan kepercayaannya itu". Penelitian ini diharapkan dapat memberikan pemahaman kepada para stakeholder terkait Keabsahan Perkawinan yang dilakukan oleh Penghayat Kepercayaan dan memberi perlindungan hukum secara administratif kepada Penghayat Kepercayaan. Putusan Mahkamah Konstitusi Nomor 97/PUU-XIV/2016 hadir memberikan solusi dan perlindungan hukum bagi Penghayat Kepercayaan atas pengaturan hukum administratif yang belum sepenuhnya melindungi dari keberadaan pemeluk Kepercayaan terhadap Tuhan YME. Pasca terbitnya Putusan MK tersebut, perkawinan Penghayat Kepercayaan diakui sebagai perkawinan yang sah dan membawa akibat hukum yang baik bagi anak turunannya.

Kata Kunci: Perlindungan Hukum; Penghayat Kepercayaan; Perkawinan; Hukum Administrasi.

Copyright (C) 2021 Safirah Oktavihana dan Nindia Putri Prameswari. Published in Notaire. Published by Universitas Airlangga, Magister Kenotariatan. 


\section{Pendahuluan}

Indonesia merupakan Negara yang memiliki keanekaragaman ras, suku, agama, golongan, dan budaya. Indonesia telah mengakomodir enam agama, yaitu: agama Islam, Kristen, Katolik, Hindu, Budha, dan Khong $\mathrm{Hu} \mathrm{Cu}$. Hal ini tertuang dalam ketentuan Penjelasan Pasal 1 Undang-Undang Nomor 1 Tahun 1965 tentang Pencegahan Penyalahgunaan dan Penodaan Agama (selanjutnya disebut Undang-Undang PNPS). Selain keenam agama yang diakui ini, terdapat pula keyakinan yang disebut dengan aliran Kepercayaan terhadap Tuhan Yang Maha Esa. Aliran Kepercayaan ini merupakan keyakinan Ketuhanan yang muncul dari ajaran budaya lokal Bangsa Indonesia. Dapat dikatakan bahwa pembentukan Negara Kesatuan Republik Indonesia berawal dari bersatunya komunitas masyarakat hukum adat yang kental akan kebudayaannya. ${ }^{1}$

Penghayat Kepercayaan pernah disebut dengan Kebatinan atau aliran kepercayaan. ${ }^{2}$ Pada tahun 1953, menurut Departemen Agama (DEPAG) terdapat tiga ratus enam puluh aliran kepercayaan dan kebatinan. Agama yang masuk di Indonesia berkembang sangat pesat dan menjadi keyakinan mayoritas kemudian diakui menjadi Agama resmi. Sedangkan Penghayat Kepercayaan dianggap menjadi bagian dari budaya bangsa. ${ }^{3}$ Menurut IGN Nurdjana dalam buku Hukum dan Aliran Kepercayaan Menyimpang di Indonesia pada tahun 2009, Penghayat Kepercayaan dapat dibagi menjadi 4 (empat) bagian yaitu: ${ }^{4}$

1. Agama lokal yang berbaur dengan budaya setempat, beberapa diantaranya: Suku Manyaan di Kalimantan Tengah, Suku Dayak Kaharingan, Sunda Wiwitan, di Kanekes Banten, Djawa Sunda di Kuningan Jawa Barat, Suku Tolotang di Sulawesi Selatan, Suku Badui, Suku Marapu di Sumba.

2. Kepercayaan terhadap Tuhan Yang Maha Esa, beberapa diantaranya yaitu : aliran kebatinan Kejawen di Jawa yaitu Sumarah, Susila Budi Dharma (Subud),

${ }^{1}$ Aan Andrianih, 'Perlindungan Negara Terhadap Keyakinan Beragama bagi Masyarakat Hukum Adat Terkait Permasalahan Kolom Agama pada Dokumen Kependudukan' (2009) Jurnal Rechtvinding.[1].

${ }^{2}$ Ketetapan Majelis Permusyawaratan Rakyat Nomor IV/MPR/1973 tentang Garis-Garis Besar Haluan Negara.

${ }^{3}$ Winda Wijayanti, Penghayat Kepercayaan Perlindungan Hukum melalui Hukum Administrasi (Rajawali Pers 2019).[5].

${ }^{4}$ IGN Nurdjana, Hukum dan Aliran Kepercayaan Menyimpang di Indonesia: Peran Polisi, Bakorpakem dan Pola Penanggulangan (Pustaka Pelajar 2009).[53]. 
Perjalanan, Sapta Darma, Budi Luhur, dan lain-lain.

3. Kepercayaan berindikasi agama : sekte keagamaan, aliran keagamaan, jemaah keagamaan, seperti Ahmadiyah, Buda Jawi Wisnu, dan lainlain.

4. Klenik atau Kepercayaan mistik : paranormal, dukun, pengobatan, santet, dan lain-lain.

Sejak Indonesia merdeka tahun 1945, sudah tertuang aturan dasar yaitu Undang-Undang Dasar Negara Republik Indonesia Tahun 1945 (selanjutnya disebut UUD NRI 1945) tentang kebebasan memeluk agama dan kepercayaan. Rumusan HAM dalam UUD NRI 1945 menjamin hak asasi setiap warga Negara dan penduduk Indonesia untuk memeluk suatu agama dan/atau suatu kepercayaan serta tidak diperlakukan secara diskiriminatif. ${ }^{5}$

Aturan yang memfasilitasi masyarakat Penghayat Kepercayaan baru disahkan pada tahun 2006, dengan diterbitkannya Undang-Undang No. 23 Tahun 2006 tentang Administrasi Kependudukan (selanjutnya disebut Undang-Undang Adminduk), yang tertuang pada Pasal 61 ayat (2) yaitu:

“Keterangan mengenai kolom agama sebagaimana dimaksud pada ayat (1) bagi Penduduk yang agamanya belum diakui sebagai agama berdasarkan ketentuan Peraturan Perundang-undangan atau bagi PenghayatKepercayaan tidak diisi, tetapi tetap dilayani dan dicatat dalam database Kependudukan".

Aturan ini terkesan terlambat karena selama enam puluh satu tahun sejak Indonesia merdeka, baru pada tahun 2006 masyarakat penghayat kepercayaan diakui secara legal oleh Negara dan dapat mencantumkan identitasnya dalam KTP, dengan mengkosongkan kolom agamanya dan diisi dengan tanda garis datar saja. Sebelum adanya Undang-Undang Adminduk ini, Penghayat Kepercayaan dianggap tidak ada di Indonesia, pemeluk ajaran Ketuhanan dari budaya lokal bangsa dipaksa untuk memeluk satu agama dari enam agama yang diakui di Indonesia seperti yang diatur pada Undang-Undang PNPS.

Ketentuan dalam Undang-Undang Adminduk yang awalnya dinilai sebagai angin segar, namun justru membawa petaka dan semakin meruncingnya

\footnotetext{
${ }^{5}$ Mahkamah Konstitusi Republik Indonesia, 'Majalah Konstitusi: Elemen Data Kependudukan Penghayat Kepercayaan' (Sekretariat Jenderal dan Kepaniteraan Mahkamah Konstitusi, 2017), < https:// www.mkri.id/public/content/infoumum/majalahkonstitusi/pdf/Majalah_133_1.\%20 Edisi\%20November\%202017\%20.pdf> diakses pada tanggal 21 Februari 2020.
} 
diskiriminasi. Akibat dari aturan Undang-Undang Adminduk tersebut membawa dampak bagi penganut Penghayat Kepercayaan yakni kesulitan dalam mencari pekerjaan, mengakses pendidikan, melakukan perkawinan secara kepercayaannya, pencatatan akta kelahiran, prosesi pemakaman, tempat ibadah, dan sulit mengakses hak atas jaminan sosial. Hal ini diakibatkan dengan stigma masyarakat yang menilai bahwa status Penghayat Kepercayaan dengan tanda garis datar pada KTP menyimpulkan memiliki arti kolot, atheis, kafir, dan sesat. ${ }^{6}$

Atas keadaan tersebut Penghayat Kepercayaan mengalami kerugian konstitusional. Para Penghayat Kepercayaan mengajukan judicial review ke Mahkamah Konstitusi atas Pasal 61 ayat (1) dan ayat (2), Pasal 64 ayat (1) dan ayat (5) Undang-Undang Adminduk yang dinilai bertentangan dengan Pasal 28E UUD NRI 1945 atau aturan lainnya yang berkenaan dengan jaminan perlakukan yang sama dan adanya diskriminatif dalam memperoleh layanan publik.

Hasil dari Putusan Mahkamah Konstitusi ini adalah memutuskan mengabulkan seluruh isi permohonan para pemohon yaitu Penghayat Kepercayaan, yang menjadi Putusan Nomor 97/PUU-XIV/2016 yang dibacakan oleh Ketua Mahkamah Kontitusi Arief Hidayat, isi putusannya adalah:

1. Mengabulkan permohonan pemohon untuk seluruhnya;

2. Menyatakan kata "agama" dalam Pasal 61 ayat (1) dan Pasal 64 ayat (1) UU Administrasi Kependudukan bertentangan dengan UUD NRI 1945 dan tidak mempunyai kekuatan hukum mengikat secara bersyarat sepanjang tidak termasuk "kepercayaan";

3. Menyatakan Pasal 61 ayat (2) dan Pasal 64 ayat (5) UU Administrasi Kependudukan bertentangan dengan UUD NRI 1945 dan tidak mempunyai kekuatan hukum mengikat;

4. Memerintahkan putusan ini dimuat ke dalam Berita Negara Republik Indonesia sebagaimana mestinya. ${ }^{7}$

Hasil Putusan Mahkamah Konstitusi yang mengabulkan seluruh permohonan dari Penghayat Kepercayaan menjadi hal yang baik bagi penganut Penghayat Kepercayaan karena masyarakat penganut Penghayat Kepercayaan

${ }^{6}$ Hani Adhani, 'Penghayat Kepercayaan Didiskriminasi?' (Antara News, 2018) <https:// kl.antaranews.com/berita/3431/penghayat-kepercayaan-didiskriminasi> diakses pada tanggal 10 Februari 2020.

${ }^{7}$ Putusan Mahkamah Konstitusi Nomor Putusan Nomor 97/PUU-XIV/2016.[154-155]. 
dapat menikmati pelayanan publik yang sama dan sejajar dengan penganut agama yang lain. Pelayanan publik yang selama ini sebelum adanya Putusan Mahkamah Kontitusi terasa sulit untuk didapatkan oleh masyarakat Penghayat Kepercayaan, sekarang dapat dilakukan seperti pendaftaran penduduk atau perubahan dalam KTP dan KK, kemudian pencatatan kelahiran dan perkawinan, serta pelayanan publik yang lain.

Proses kehidupan manusia adalah lahir, hidup tumbuh menjadi anak, dewasa, dan meninggal dunia. Indonesia sebagai Negara hukum mempunyai kebijakan dalam pengaturan dalam proses tersebut, agar tertibnya pencatatan administrasi dan menghindari permasalahan hukum di kemudian hari. Salah satunya yaitu menyangkut tentang perkawinan. Proses perkawinan adalah proses penting dalam kehidupan manusia, karena dalam proses ini akan timbul proses tumbuhnya generasi baru yaitu kelahiran seorang anak.

Undang-Undang Nomor 1 Tahun 1974 tentang Perkawinan (selanjutnya disebut Undang-Undang Perkawinan) Pasal 1 menyebutkan definisi dari Perkawinan adalah ikatan lahir batin antara seorang pria dengan seorang wanita sebagai suami istri dengan tujuan membentuk keluarga (rumah tangga) yang bahagia dan kekal berdasarkan Ketuhanan Yang Maha Esa. Perkawinan yang sah diatur pula dalam Pasal 2 ayat (1) Undang-Undang Perkawinan. Dalam Pasal 2 ayat (1) Undang-Undang Perkawinan dan penjelasannya dapat diketahui bahwa perkawinan mutlak harus dilakukan menurut hukum masing-masing agamanya dan kepercayaannya itu.

Salah satu dampak dari istilah 'perkawinan yang sah' yang diatur dalam Undang-Undang Perkawinan ini dirasakan oleh Gumirat Barna Alam dan Susilawati. ${ }^{8}$ Dalam kasus ini, perkawinan Gumirat dan Susilawati yang merupakan Penghayat Kepercayaan dari Aliran Kebatinan Perjalanan telah dinilai bermasalah di mata Negara. Selama tiga belas tahun, Negara memandang perkawinan mereka yang dilaksanakan dengan adat sunda tidak legal secara hukum, karena tidak

\footnotetext{
${ }^{8}$ Heru Susetyo, 'Pencatatan Perkawinan bagi Golongan Penghayat' (2017) 28 Jurnal Hukum dan Pembangunan.[149].
} 
dicatatatkan di Kantor Catatan Sipil. Akibat hukum dalam kasus ini bermasalah dengan anak-anak yang lahir dalam perkawinan mereka. Anak-anak yang lahir dalam perkawinan yang tidak sah tidak mempunyai hubungan hukum dengan bapaknya dan akan berakibat pada pembagian waris, maka hal ini bertentangan dengan UUD RI 1945 Pasal 28D yaitu "Setiap orang berhak atas pengakuan, jaminan, perlindungan, dan kepastian hukum yang adil serta perlakuan yang sama dihadapan hukum".

Pembatasan dalam Pasal 2 ayat (1) Undang-Undang Perkawinan juga dirasakan oleh Asep Setia Pujanegara dan Rela Susanti yang merupakan penganut kepercayaan Sunda Wiwitan. Kepala Dinas Kependudukan dan Catatan Sipil Kabupaten Bandung (selanjutnya disebut KCS Bandung), menolak mencatatatkan perkawinan mereka karena perkawinan mereka dilaksanakan menurut adat sunda. Asep dan Rela kemudian menggugat KCS Bandung di Pengadilan Tata Usaha Negara Bandung yang selanjutnya disebut PTUN Bandung. Pada 22 April 2002, PTUN Bandung memutuskan menghukum KCS Bandung untuk mencatatkan perkawinan keduanya. Putusan PTUN Bandung ini diperkuat oleh Pengadilan Tinggi TUN Jakarta dan kemudian memiliki kekuatan hukum mengikat setelah Mahkamah Agung menolak kasasi yang diajukan oleh KCS Bandung. ${ }^{9}$

Pada tanggal 24 Desember 2013, Presiden Susilo Bambang Yudhoyono telah menandatangani dan mengesahkan Undang-Undang Nomor 24 Tahun 2013 tentang Perubahan atas Undang-Undang Nomor 23 Tahun 2006 tentang Administrasi Kependudukan (selanjutnya disebut Undang-Undang Adminduk). Pada Pasal 8 ayat (4) mengatur tentang pencatatan peristiwa penting termasuk dengan perkawinan yang dilakukan oleh Penghayat Kepercayaan menyebutkan:

"Kewajiban sebagaimana dimaksud pada ayat (1) untuk persyaratan dan tata cara Pencatatan peristiwa penting bagi Penduduk yang agamanya belum diakui sebagai agama berdasarkan ketetuan Peraturan PerundangUndangan atau bagi Penghayat Kepercayaan yang berpedoman pada Peraturan Perundang-Undangan". 
Pemerintah kemudian mengeluarkan Peraturan Pemerintah Nomor 40 Tahun 2019 tentang Pelaksanaan Undang-Undang Nomor 23 Tahun 2006 tentang Administrasi Kependudukan sebagaimana telah diubah dengan Undang-Undang Nomor 24 Tahun 2013 tentang Perubahan atas Undang-Undang Nomor 23 Tahun 2006 tentang Administrasi Kependudukan, yang isinya mengatur tentang kewenangan dan proses penyelenggaraan dalam pelaksanaan pencatatan sipil. Persyaratan dan tata cara pencatatan perkawinan bagi penghayat kepercayaan diatur pada Bab VI PP Nomor 37 Tahun 2007, di dalamnya tertulis bahwa perkawinan Penghayat Kepercayaan dilakukan di hadapan pemuka Penghayat Kepercayaan yang ditunjuk dan ditetapkan oleh organisasi Penghayat Kepercayaan sebagai suatu wadah Penghayat Kepercayaan yang terdaftar pada instansi yang membidangi pembinaan teknis kepercayaan kepada Tuhan Yang Maha Esa.

Setelah adanya Undang-Undang Nomor 24 Tahun 2013 tentang Perubahan atas Undang-Undang Nomor 23 Tahun 2006 tentang Administrasi Kependudukan jo. PP Nomor 37 Tahun 2007 tentang Pelaksanaan Undang-Undang Nomor 23 Tahun 2006 tentang Administrasi Kependudukan, dan diperkuat dengan Putusan MK Nomor 97/PUU-XIV/2016 perkawinan yang dilakukan oleh Penghayat Kepercayaan dapat dicatatkan di Kantor Catatan Sipil. Masyarakat Penghayat Kepercayaan, yang awal mulanya tidak dipayungi oleh perlindungan hukum yang kuat, kemudian muncul adanya Putusan Mahkamah Konstitusi Nomor 97/PUUXIV/2016 terkait dengan Undang-Undang Adminduk tentu membawa dampak yang baik yaitu perlindungan dan pengakuan secara hukum bagi Penghayat Kepercayaan, termasuk dalam hal pencatatan perkawinan.

Maka sahnya suatu perkawinan yang dilakukan oleh pasangan suami istri Penghayat Kepercayaan, akan berhubungan dengan status anak dan permasalahan waris di kemudian hari. Berdasarkan latar belakang diatas, maka dengan karya ilmiah ini akan dibahas mengenai keabsahan perkawinan Penghayat Kepercayaan pasca terbitnya Putusan Mahkamah Konstitusi Nomor 97/PUU-XIV/2016 dan akibat hukum dari perkawinan yang dilakukan oleh Penghayat Kepercayaan. 


\section{Metode Penelitian}

Metodeyang digunakan dalam penelitianiniadalahmetode penelitianhukum normatif yang merupakan implikasi dari sebuah legal research, untuk menemukan kebenaran berdasarkan logika keilmuan hukum dari sisi normatifnya. ${ }^{10}$

Pendekatan yang digunakan adalah pendekatan perundang-undangan (statute approach), pendekatan konseptual (conceptual approach), dan studi kasus (case study). Pendekatan perundang-undangan dilakukan dengan menganalisa semua undang-undang yang memiliki kaitan dengan isu hukum yang diteliti yaitu Agama, Kepercayaan, dan Perkawinan. Pendekatan konseptual menjadi pedoman penting untuk membangun argumentasi saat menyelesaikan isu hukum dalam penelitian ini. Pada pendekatan ini, beranjak dari doktrin-doktrin dan pandangan-pandangan yang berkembang berkaitan dengan Penghayat Kepercayaan dan Perkawinan. Studi kasus merupakan pendekatan penelitian yang menggunakan pemahaman isu hukum yang dapat berupa suatu kejadian, proses, kegiatan dari satu atau beberapa orang. Pendekatan ini dibutuhkan untuk menjawab rumusan masalah dengan melihat dan meneliti atas kejadian yang ada.

\section{Perkawinan Penghayat Kepercayaan}

Ketuhanan Yang Maha Esa merupakan hal yang penting bagi tiap kehidupan manusia, sebagai pedoman dan penuntun dalam kehidupan. Proses kehidupan manusia mulai dari lahir, tumbuh dari anak hingga dewasa, kemudian meninggal dunia mempengaruhi pola penghayatannya terhadap Tuhan Yang Maha Esa, dan penghayatan tersebut tumbuh berbeda-beda di setiap manusia. Maka negara memberikan perlindungan hukum melalui UUD NRI 1945.

Penghayat Kepercayaan yang terdapat di Indonesia, merujuk pada ajaran ketuhanan yang tidak bersandarkan kepada ajaran-ajaran agama yang diakui oleh negara. Dengan demikian, dalam kehidupan bermasyarakat dan perilaku moral 
sehari-hari, sekaligus kegiatan menyembah Tuhan, penganut dari Penghayat Kepercayaan tidak berpegang pada suatu ajaran agama tertentu.

Sebagai negara hukum, Indonesia mengatur seluruh keberlangsungan peristiwa penting bagi penduduknya, begitu pula dengan perkawinan. Proses perkawinan adalah salah satu proses terpenting dalam kehidupan manusia. Perkawinan tidak hanya menyangkut pribadi kedua calon suami istri, namun juga menyangkut urusan keluarga dan masyarakat. ${ }^{11}$ Pada umumnya, perkawinan dianggap sebagai sesuatu yang suci dan oleh karena itu setiap agama selalu menghubungkan kaedah perkawinan dengan kaedah agama. ${ }^{12}$

Perkawinan juga diatur dalam UUD NRI 1945, yang merupakan pedoman dalam seluruh aturan perundang-undangan di Indonesia. Pasal 28B ayat (1) UUD NRI 1945 menyebutkan bahwa "setiap orang berhak membentuk suatu keluarga dan melanjutkan keturunan melalui perkawinan yang sah". Kalimat 'perkawinan yang sah' merujuk pada aturan lain yang mengatur khusus tentang perkawinan.

Bila ditinjau secara segi hukum, perkawinan merupakan salah satu bentuk sebuah perjanjian dan perbuatan hukum. Perkawinan adalah suatu perjanjian suci, kuat dan kokoh untuk hidup bersama secara sah antara seorang laki-laki dengan seorang perempuan membentuk keluarga yang kekal, santun-menyantuni, kasih-mengasihi, tentram, dan bahagia. Setiap perbuatan hukum menimbulkan berbagai akibat hukum, begitu pula dengan perkawinan. Sah atau tidak nya suatu perkawinan, harus diatur secara jelas dalam sebuah aturan hukum positif. Hukum positif yang mengatur tentang perkawinan adalah Undang-Undang Nomor 1 Tahun 1974 tentang Perkawinan.

Kalimat 'perkawinan yang sah' yang terdapat di Pasal 28B ayat (1) UUD NRI 1945 dijelaskan lebih lanjut dalam UU Perkawinan. Pasal 2 ayat (1) UU Perkawinan menerangkan "Perkawinan adalah sah apabila dilakukan menurut hukum masing-masing agamanya dan kepercayaan nya itu". Dengan penjelasan

\footnotetext{
${ }^{11}$ Rizky Sabilatus Safina dan Fauzul Aliwarman, 'Akibat Hukum Perkawinan Penghayat Kepercayaan di Indonesia' (2020), 01 Prohutek Prosiding Seminar Nasional Hukum dan Teknologi. [582]. 12 ibid.[583].
} 
pasal tersebut yaitu :

“Dengan perumusan pada Pasal 2 ayat (1) ini, tidak ada perkawinan di luar hukum masing-masing agamanya dan kepercayaan nya itu, sesuai dengan Undang-Undang Dasar Negara Republik Indonesia 1945. Yang dimaksud dengan hukum masing-masing agamanya dan kepercayaannya itu termasuk ketentuan perundang-undangan yang berlaku bagi golongan agamanya dan kepercayaannya itu sepanjang tidak bertentangan atau tidak ditentukan lain dalam undang-undang ini". ${ }^{13}$

Pasal 2 ayat (1) UU Perkawinan beserta penjelasannya menunjukan bahwa perkawinan harus sesuai dengan aturan agama dan kepercayaan adalah mutlak. Namun, terdapat ambiguitas atas kata 'agamanya dan kepercayaannya' dalam Pasal 2 UU Perkawinan. Ambiguitas tersebut yaitu mengenai agama dan kepercayaan ini bermakna kepercayaan dasar agama atau merujuk spesifik ke aliran kepercayaan. ${ }^{14}$

Syarat lain melaksanakan suatu perkawinan dalam Undang-Undang Perkawinan meliputi 2 (dua) hal yaitu: ${ }^{15}$

1. Syarat Materiil, yaitu syarat perkawinan yang menyangkut diri pribadi calon suami dan istri yang akan melaksanakan perkawinan.

2. Syarat Formil, yaitu syarat perkawinan yang menyangkut tata cara yang wajib dilakukan sebelum dan sesudah perkawinan dilaksanakan.

Syarat yang pertama yaitu syarat materiil, bila syarat ini tidak dipenuhi maka akan mengakibatkan batalnya suatu perkawinan. Syarat materiil ini meliputi beberapa hal yaitu:

a. Harus ada persetujuan dari kedua belah pihak, syarat ini tertuang pada Pasal 6 ayat (1) yang bertujuan untuk menghindari kawin paksa.

b. Usia kedua belah pihak baik laki-laki dan perempuan adalah minimal 19 (sembilan belas) tahun, hal ini tertuang pada Pasal 7 ayat (1) Undang-Undang Nomor 16 Tahun 2019 tentang Perubahan atas Undang-Undang Nomor 1 Tahun 1974 tentang Perkawinan.

c. Tidak terikat perkawinan dengan orang lain, yang tertuang pada Pasal 9 Undang-Undang Perkawinan. Hal ini sesuai dengan tujuan prinsip perkawinan di Indonesia yaitu monogami.

${ }^{13}$ Penjelasan Pasal 2 ayat (1) Undang-Undang Nomor 1 Tahun 1974 tentang Perkawinan.

${ }^{14}$ Rizky Sabilatus Safina dan Fauzul Aliwarman, Op.Cit.[585].

${ }^{15}$ Sirman Dahwal, Perbandingan Hukum Perkawinan (Mandar Maju 2017).[73]. 
d. Tenggang waktu bagi janda untuk melakukan perkawinan kembali, tertuang pada Pasal 11 Undang-Undang Perkawinan, dan diatur lebih lanjut dalam Pasal 9 Peraturan Pemerintah Nomor 9 Tahun 1975 tentang Pelaksanaan Undang-Undang Perkawinan.

e. Perkawinan yang tidak melanggar Undang-Undang Perkawinan. Syarat ini diatur pada Pasal 8 Undang-Undang Perkawinan.

Syarat yang kedua adalah syarat formil, yang tertuang dalam Peraturan Pemerintah Nomor 9 Tahun 1975 tentang Pelaksanaan Undang-Undang Nomor 1 Tahun 1974 tentang Perkawinan. Di dalam peraturan ini berisi beberapa hal yang harus dilaksanakan demi sah nya suatu perkawinan, diantaranya tentang pencatatan perkawinan dan tata cara perkawinan.

Salah satu syarat sahnya perkawinan adalah dengan mencatatkan perkawinannya. Pencatatan perkawinan diatur secara khusus dalam Peraturan Pemerintah Nomor 9 Tahun 1975 tentang Pelaksanaan Undang-Undang Nomor 1 Tahun 1974 tentang Perkawinan. Dalam peraturan ini memuat tentang aturan pencatatan perkawinan. Selain itu, perihal tentang pencatatan perkawinan juga diatur dalam Undang-Undang Adminduk.

Dalam Pasal 2 Peraturan Pemerintah Nomor 9 Tahun 1975 tentang Pelaksanaan UU Perkawinan menyatakan bahwa pencatatan perkawinan hanya dilakukan oleh 2 (dua) instansi yaitu : bagi penduduk yang beragama Islam dapat mencatatkan perkawinanya di Kantor Urusan Agama dan bagi penduduk yang beragama selain agam Islam (Kristen, Protestan, Hindu, Budha, Khong $\mathrm{Hu} \mathrm{Chu}$ ) dapat mencatatkan perkawinan nya di Kantor Catatan Sipil.

Bahwa keberadaan dari ajaran Ketuhanan dari kearifan lokal di Indonesia masih ada di negara ini. Keberadaan nya masih eksis dan diakui. Namun, pengakuan itu belum sejalan dengan aturan aturan lainnya khususnya dalam bidang perkawinan. Beberapa masyarakat Penghayat Kepercayaan banyak yang menuntut tentang belum adanya dasar hukum tentang perkawinan bagi penganut Kepercayaan. Tidak adanya aturan yang memayungi perkawinan masyarakat penganut Penghayat Kepercayaan mengakibatkan perkawinan tersebut tidak dapat dicatatkan secara legal sesuai aturan negara, dan perkawinan hanya dilaksanakan secara adat, dengan kata lain, perkawinan tersebut merupakan 
perkawinan yang tidak sah. Bahwa, pada zaman Orde Baru terdapat kondisi dimana sebagian pasangan Penghayat Kepercayaan dapat dicatatkan perkawinannya dan sebagiannya lagi ditolak pencatatannya di Kantor Catatan Sipil. ${ }^{16}$

Tuntutan Penghayat Kepercayaan menggunakan dalil Undang-Undang Hak Asasi Manusia (selanjutnya disebut UU HAM) Pasal 10 ayat (1) yang berbunyi "Setiap orang berhak membentuk suatu keluarga dan melanjutkan keturunan melalui perkawinan yang sah", dilanjutkan dalam ayat (2) yaitu "Perkawinan yang sah hanya dapat berlangsung atas kehendak bebas calon suami dan calon istri yang bersangkutan, sesuai dengan ketentuan peraturan perundang-undangan". Sesuai dengan ketentuan dalam UU HAM tersebut, dapat diketahui bahwa setiap orang di Indonesia berhak melakukan perkawinan yang sah.

Munculnya Undang-Undang Nomor 23 Tahun 2006 tentang Administrasi Kependudukan memberi keleluasaan bagi masyarakat penganut Kepercayaan. Dalam UU Adminduk ini mengatur tentang pencatatan perkawinan bagiPenghayat Kepercayaan, yaitu pada Pasal 8 ayat (4) yang isinya “... untuk persyaratan dan tata cara Pencatatan Peristiwa Penting bagi Penduduk yang agamanya belum diakui sebagai agama menurut peraturan perundang-undangan atau bagi penghayat kepercayaan berpedoman pada peraturan perundang-undangan."

Dijelaskan lebih lanjut dalam Pasal 105 UU Adminduk bahwa “Dalam waktu 6 (enam) bulan sejak diundangkannya Undang-Undang ini, Pemerintah wajib menerbitkan Peraturan Pemerintah yang mengatur tentang penetapan persyaratan dan tata cara perkawinan bagi para Penghayat Kepercayaan sebagai dasar diperolehnya kutipan akta perkawinan dan pelayanan pencatatan Peristiwa Penting". Atas dasar dari Pasal tersebut, Pemerintah menerbitkan Peraturan Pemerintah (selanjutnya disebut PP) Nomor 37 Tahun 2007 tentang Pelaksanaan Undang-Undang Nomor 23 Tahun 2006 tentang Administrasi Kependudukan. Dalam PP ini diatur mengenai Persyaratan dan Tata Cara Pencatatan Perkawinan bagi Penghayat Kepercayaan yang dijabarkan dalam Pasal 81-83 PP Nomor 37 Tahun 2007.

${ }^{16}$ Rizky Sabilatus Safina dan Fauzul Aliwarman, Op.Cit.[586]. 
Perkawinan Penghayat Kepercayaan dapat dilakukan di hadapan Pemuka Penghayat, hal ini tertuang pada Pasal 81 ayat (1) PP Nomor37 Tahun 2007. Pemuka Penghayat ini ditunjuk dan ditetapkan oleh organisasi penghayat kepercayaan, dan surat tugasnya dibuat dan ditandatangani oleh Kementerian Pendidikan dan Kebudayaan Direktorat Jendral Kebudayaan, Direktorat Kepercayaan Terhadap Tuhan Yang Maha Esa dan Tradisi.

Perkawinan yang dilaksanakan Penghayat Kepercayaan sesuai dengan aturan PP diatas juga menghasilkan sebuah kepastian hukum atas perkawinan tersebut dengan lahirnya Kutipan Akta Perkawinan yang dikeluarkan oleh Kantor Catatan Sipil, ketentuan ini diatur pada Pasal 83 ayat PP Nomor 37 Tahun 2007.

Meskipun isi dari UU Adminduk memberi harapan bagi masyarakat Penghayat Kepercayaan untuk mencatatkan perkawinan nya secara legal, namun mendapat keleluasaan bukan berarti tanpa kekurangan, karena di dalam UU Adminduk juga terdapat celah yang tetap akan mendiskriminasi masyarakat Penghayat Kepercayaan. Dalam Pasal34 ayat (1) UU Adminduk yang menyebutkan "Perkawinan yang sah menurut peraturan perundang-undangan....".

Kalimat 'perkawinan yang sah' akan dikaitkan dengan UU Perkawinan, karena sesuai dengan asas hukum, yaitu Lex Specialis Derogat Legi Generalis yang artinya aturan yang sifatnya khusus akan mengesampingkan aturan itu yang sifatnya umum. Dari pembahasan penulisan ini, dapat diketahui bahwa UU Perkawinan merupakan aturan khusus yang membahas tentang pelaksanaan perkawinan di Indonesia. Segala sesuatu yang bersangkutan dengan perkawinan harus di dasarkan pada UU Perkawinan.

Pasal 34 ayat (1) UU Adminduk akan dikaitkan dengan Pasal 2 ayat (1) UU Perkawinan, yang menerangkan bahwa perkawinan yang sah adalah perkawinan yang didasarkan atas agama dan kepercayaannya itu, dan tidak ada perkawinan diluar agama dan kepercayaannya itu. Dapat diketahui bahwa kedua aturan ini adalah tumpang tindih dan saling bertolak belakang. Namun bila dikaitkan dengan asas hukum Lex Specialis Derogat Legi Generalis, maka UU Perkawinan harus lebih di dahulukan daripada UU Adminduk dalam hal pengaturan perkawinan. 
Ketidakharmonisan peraturan perundang-undangan antara Pasal 2 Undang-Undang Nomer 1 Tahun 1974 tentang Perkawinan, dengan Pasal 81 ayat (1) PP Nomor 37 Tahun 2007 sebagai pelaksana dari Pasal 105 Undang-Undang Nomor 23 Tahun 2006 mengenai perkawinan yang dilakukan oleh Penghayat Kepercayaan, diperlukan penafsiran sistematis atau logis yang menafsirkan bahwa undang-undang sebagai bagian dari seluruh sistem perundang-undangan yang menghubungkan dengan undang-undang lain. ${ }^{17}$

\section{Keabsahan Perkawinan Penghayat Pasca Putusan MK Nomor 97/PUU-XIV/2016}

Prinsip perkawinan yang tertuang pada Pasal 1 UU Nomor 1 Tahun 1974 tentang Perkawinan yaitu ikatan lahir batin antara seorang pria dan seorang wanita, dengan tujuan membentuk keluarga, dijelaskan lebih lanjut pada Penjelasan Pasal 1 yang berbunyi "Sebagai negara yang berdasarkan Pancasila, dimana sila pertamanya ialah Ketuhanan Yang Maha Esa, maka perkawinan mempunyai hubungan erat sekali dengan agama/kerohanian sehingga perkawinan bukan saja mempunyai peranan yang penting.....".

Perkawinan di Indonesia tidak lepas dari prinsip Ketuhanan Yang Maha Esa menurut Pasal 29 ayat (2) UUD NRI 1945 bahwa negara berdasar Ketuhanan Yang Maha Esa. Hal ini berimplikasi pada seluruh bidang kehidupan, mulai dari politik, ekonomi, sosial, pendidikan, perkawinan, budaya, hingga pertahanan dan keamanan negara. Penafsiran atas kata agama dan kepercayaan oleh Hakim Konstitusi melalui Mahkamah Konstitusi yang memiliki kewenangan atas penafsiran undang-undang menegaskan bahwa agama dan kepercayaan diletakkan sebagai sesuatu yang terpisah. ${ }^{18}$ Pasal 28E UUD NRI 1945 pada ayat (1) mengatur tentang agama bahwa setiap orang berhak memeluk agama dan beribadat menurut agamanya. Pada ayat (2) pasal ini mengatur tentang kepercayaan bahwa setiap orang berhak atas kebebasan meyakini kepercayaan, menyatakan pikiran

${ }^{17}$ Siti Malikhatun Badriyah, Sistem Penemuan Hukum dalam Masyarakat Prismatik (Sinar Grafika 2016).[17].

${ }^{18}$ Winda Wijayanti, Op.Cit.[274]. 
dan sikap sesuai dengan hati nuraninya.

Agama dan kepercayaan juga dianggap sebagai dua hal yang setara, ${ }^{19}$ hal ini diatur dalam Pasal 29 UUD NRI 1945 yang menyebutkan "Negara menjamin kemerdekaan tiap-tiap penduduk untuk memeluk agamanya masing-masing dan untukberibadatmenurutagamanya dankepercayaannyaitu." Bilakata 'kepercayaan' dianggap merupakan satu bagian dari agama, maka frasa 'kepercayaan' tidak akan digunakan dalam Pasal 29 UUD NRI 1945, melainkan hanya menggunakan frasa agama menjadi "untuk beribadat menurut agamanya itu". Sesuai dengan tata syarat perumusan norma, kata penghubung 'dan' digunakan sebagai sesuatu yang dirumuskan secara kumulatif, maka keduanya adalah dua hal yang dapat dikelompokkan secara berbeda. Jika dipahami dengan arti yang sama, maka tidak akan ada kata penghubung 'dan' dalam Pasal 29 UUD NRI 1945. ${ }^{20}$

Pembentukan sebuah hukum harus berdasarkan keutuhan karakteristik permasalahan dengan pertimbangan komprehensif, yaitu dengan mempertimbangkan seluruh aspek meliputi ruang lingkup yang luas. Bila penerapan hukum tidak mencangkup seluruh sisi permasalahan, maka hukum akan menjadi rusak dan akan merusak kehidupan masyarakatnya.

Perkawinan adalah suatu proses yang baik dalam kehidupan, memiliki tujuan luhur untuk membentuk suatu keluarga. Pengertian eksklusif dalam Pasal 2 ayat (1) UU Perkawinan menyebabkan pembatasan dalam hukum perkawinan bagi Penghayat Kepercayaan, dan hal ini akan berdampak dengan merusak tujuan luhur dari perkawinan itu sendiri. Pembentukan UU Perkawinan seharusnya memperhatikan karakteristik khusus dalam bentuk pengakuan negara atas pluralisme masyarakat Indonesia yang memiliki keanekaragaman di dalamnya.

Pasca terbitnya Putusan MK Nomor 97/PUU-XIV/2016, keabsahan pencatatan perkawinan yang dilaksanakan oleh Penghayat Kepercayaan adalah legal di mata hukum. Sesuai dengan asas Lex Specialis Derogat Legi Generalis sebagai peraturan khusus yang mengatur tentang perkawinan di Indonesia, Undang-

\footnotetext{
${ }^{19}$ Putusan Mahkamah Konstitusi Nomor 97/PUU-XIV/2016.[144-145].

${ }^{20}$ Winda Wijayanti, Op.Cit.[234].
} 
Undang Nomor 1 Tahun 1974 tentang Perkawinan harus tunduk dan tidak boleh bertentangan dengan UUD NRI 1945 terkait dengan Pasal 28B ayat (1) bahwa setiap orang mempunyai hak atas perkawinan yang sah tanpa ada diskriminasi atas dasar apapun, karena UUD NRI 1945 menempati hierarki tertinggi dari perundangundangan. Dengan adanya putusan MK tersebut, penyetaraan kedudukan antara Penghayat Kepercayaan dan agama di Indonesia dapat diterapkan terhadap pelaksanaan ketentuan UU Perkawinan sehingga Penghayat Kepercayaan yang aliran kepercayaannya tercantum dalam putusan tersebut tunduk dan taat terhadap ketentuan UU Perkawinan. ${ }^{21}$

Kemudian makna 'agama' dalam syarat keabsahan perkawinan Pasal 2 ayat (1) UU Perkawinan, harus tunduk dan mengikuti Putusan MK Nomor 97/PUUXIV/2016, yang menyatakan bahwa kata 'agama' dalam Pasal 61 ayat (1) dan Pasal 64 ayat (1) UU Adminduk bertentangan dengan UUD NRI 1945 dan tidak memiliki kekuatan hukum mengikat secara bersyarat sepanjang tidak termasuk 'kepercayaan'. Dalam Putusan MK ini menjelaskan bahwa agama tidak terikat pada agama saja, tetapi juga kepercayaan terhadap Tuhan Yang Maha Esa masuk kedalamnya, sebagai penafsiran inklusif yang mengakui keanekaragaman. ${ }^{22}$

Syarat sah nya perkawinan yang dilakukan oleh Penghayat Kepercayaan, diatur pada Peraturan Pemerintahan Nomor 37 Tahun 2007 tentang Pelaksanaan Undang-Undang Nomor 23 Tahun 2006 tentang Administrasi Kependudukan. Bahwa perkawinan adat yang dilakukan oleh Penghayat Kepercayaan menjadi sah di mata hukum bila dilaksanakan menurut kepercayaan di hadapan Pemuka Penghayat Kepercayaan, dan wajib untuk didaftar dan dicatat di Kantor Catatan Sipil, selanjutnya Pejabat Kantor Catatan Sipil wajib untuk mencatatkan perkawinan itu sebagai perkawinan yang sah.

Melalui perjuangan yang panjang, Penghayat Kepercayaan akhirnya mendapat kedudukan yang sama di mata hukum, setara dan sejajar dengan

\footnotetext{
${ }^{21}$ Herni Widanarti dan Rinitami Njatrijani, 'Implementasi Putusan MK No. 97/PUU-XIV/2016 terhadap Pelaksanaan Perkawinan pada Masyarakat Adat Samin (Sedulur Sikep) di Jawa Tengah' (2019) 4 E-Journal Undip.

${ }^{22}$ Winda Wijayanti, Op.Cit.[276].
} 
penganut agama resmi di Indonesia. Setelah dikeluarkannya Putusan Mahkamah Konstitusi Nomor 97/PUU-XIV/2016 yang membawa semakin kuatnya pengakuan Penghayat Kepercayaan dalam pengakuan identitas khususnya permasalahan perkawinan. Melalui Undang-Undang Nomor 23 Tahun 2006 tentang Adminstrasi Kependudukan dan Peraturan Pemerintah Nomor 37 Tahun 2007 sebagai peraturan pelaksananya, pemerintah menentukan syarat pelaksanaan perkawinan Penghayat Kepercayaan.

Syarat untuk melakukan perkawinan oleh Penghayat Kepercayaan diatur pada Pasal 81-83 PP Nomor 37 Tahun 2006, yaitu dilaksanakan dihadapan Pemuka Penghayat Kepercayaan. Pemuka Penghayat Kepercayaan ini ditunjuk dan ditetapkan oleh organisasi Penghayat Kepercayaan yang telah terdaftar secara resmi pada instansi di kementerian yang membidangi pembinaan teknis Kepercayaan kepada Tuhan Yang Maha Esa (Instansi kementerian yang dimaksud adalah Kementerian Pendidikan dan Kebudayaan), hal ini sesuai dengan Penjelasan Pasal 81 PP Nomor 37 Tahun 2006. Kemudian pemuka Penghayat Kepercayaan akan diberikan Surat Keterangan Terdaftar yang dikeluarkan oleh Kementerian Pendidikan dan Kebudayaan melalui Direktorat Jenderal Kebudayaan.

Kemudian perkawinan tersebut wajib dilaporkankepada Instansi Pelaksana atau UPTD Instansi Pelaksana, yaitu perangkat pemerintah kabupaten/kota yang bertanggung jawab dan berwenang melaksanakan pelayanan dalam urusan Administrasi Kependudukan, dalam hal ini adalah Kantor Catatan Sipil. Setelah seluruh proses dan persyaratan telah dipenuhi, sesuai dengan Pasal 83 ayat (1) poin c PP No 37 Tahun 2006 menyebutkan bahwa Pejabat Instansi Pelaksana atau UPTD Instansi Pelaksana dalam hal ini Kantor Catatan Sipil akan menerbitkan kutipan akta perkawinan Penghayat Kepercayaan.59 Dengan adanya akta perkawinan yang merupakan bukti otentik yang dikeluarkan oleh Kantor Catatan Sipil, bahwa seorang pria dan seorang wanita telah mencatatkan perkawinannya, maka perkawinan yang dilakukan oleh Penghayat Kepercayaan telah memiliki kekuatan hukum dan setara dengan perkawinan yang dilakukan oleh penganut lain. Dari penjelasan ini, dapat diambil kesimpulan bahwa Kantor 
Catatan Sipil tidak lagi hanya mencatatkan peristiwa penting yaitu kelahiran, kematian, perkawinan, perceraian bagi penduduk yang menganut agama yang diakui negara namun juga wajib mencatatkan peristiwa penting bagi masyarakat Penghayat Kepercayaan. Sesuai dengan asas Lex Specialis Derogat Legi Generalis, Undang-Undang Perkawinan merupakan aturan khusus yang mengatur tentang perkawinan di Indonesia. Putusan MK Nomor 97/PUU-XIV/ 2016 yang mengatur dan membahas tentang Undang-Undang Adminduk yaitu tentang peristiwa penting yang salah satunya adalah persoalan perkawinan, seharusnya diikuti dengan pembaharuan undang-undang khusus yang mengatur tentang perkawinan. Sesuai dengan Undang-Undang Adminduk, perkawinan yang dilakukan oleh Penghayat Kepercayaan dapat dan sah dicatatkan secara hukum, namun keabsahan sesuai dengan Undang-Undang Perkawinan belum sepenuhnya dapat terpenuhi apabila Undang-Undang Perkawinan tidak melakukan perubahan pada pasalnya, khususnya Pasal 2 ayat (1) yaitu "Perkawinan adalah sah, apabila dilakukan menurut hukum masing-masing agamanya dan kepercayaannya itu".

\section{Akibat Hukum Perkawinan Penghayat Kepercayaan Pasca Putusan Mahkamah Konstitusi Nomor 97/PUU-XIV/2016}

Perkawinan Penghayat Kepercayaan yang tidak dapat dicatatkan membawa dampak yang sangat besar bagi masyarakat Penghayat Kepercayaan, khususnya anak yang lahir dari perkawinan tersebut. Mereka mengalami kerugian yang disebabkan oleh konstitusi karena pembedaan yang dilakukan oleh negara atas dasar keyakinan dan beragama.

Sejak berlakunya Undang-Undang Adminduk, Penghayat Kepercayaan sudah dapat melaksanakan dan mencatatakan perkawinan sesuai dengan Kepercayaan sesuai dengan prosedur khusus, yang diatur lebih lanjut dalam Peraturan Pemerintah Nomor 37 Tahun 2007. Dalam perpres ini mengatur tentang prosedur pencatatan perkawinan yang dilakukan oleh Penghayat Kepercayaan, yaitu pada Pasal 81, 82, 83 Peraturan Pemerintah Nomor 37 Tahun 2007. 
Namun perlu dicermati kembali pada Pasal 34 UU Adminduk yang menjelaskan bahwa "Perkawinan yang sah menurut Peraturan PerundangUndangan wajib dilaporkan oleh Penduduk kepada Instansi Pelaksana...." Kalimat 'perkawinan yang sah' merujuk pada aturan hukum positif yang mengatur tentang perkawinan yaitu Undang-Undang Nomor 1 Tahun 1974 Pasal 2 ayat (1), bahwa perkawinan yang sah adalah perkawinan yang dilakukan menurut hukum masing-masing agamanya dan kepercayaannya. Dari pasal inilah yang masih menghambat Penghayat Kepercayaan untuk melaksanakan perkawinan dan tidak dapat mencatatkan perkawinan di Kantor Catatan Sipil.

Pasca Putusan Mahkamah Konstitusi Nomor 97/PUU-XIV/2016 tidak hanya berimplikasi pada pembenahan administrasi kependudukan di Indonesia terkait keberadaan Penghayat Kepercayaan, namun juga perluasan makna 'agama' dalam peraturan perundang-undangan untuk menghilangkan diskriminasi yang mengakibatkan ketidakadilan yang dirasakan oleh Penghayat Kepercayaan.

Pasca Putusan Mahkamah Konstitusi Nomor 97/PUU-XIV/2016 merubah status keabsahan perkawinan yang dilakukan oleh Penghayat Kepercayaan. Kalimat 'perkawinan yang sah' yang tercantum dalam Pasal 2 Undang-Undang Perkawinan terdapat 2 (dua) unsur hukum yang harus dipenuhi agar perkawinan tersebut dianggap sah. Yang pertama yaitu dengan dilakukan menurut hukum masing-masing agamanya dan kepercayaannya, dan yang kedua adalah perkawinan harus dicatat menurut perundang-undangan yang berlaku. Pasca terbitnya Putusan MK Nomor 97/PUU-XIV/2016 pencatatan perkawinan Penghayat Kepercayaan yang diatur dalam Undang-Undang Adminduk telah sah dah dapat dicatatkan.

Syarat 'perkawinan yang sah' pada Undang-Undang Perkawinan yang menyebutkan harus didasarkan pada hukum masing-masing agamanya dan kepercayaannya, harus tunduk pada Putusan Mahkamah Konstitusi 97/PUUXIV/2016. Makna 'agama' pada Pasal 61 ayat (1) dan Pasal 64 ayat (1) UndangUndang Adminduk bertentangan dengan UUD NRI 1945 dan tidak mempunyai kekuatan hukum mengikat secara bersyarat sepanjang tidak termasuk 
'kepercayaan'. Dalam Putusan Mahkamah Konstitusi Nomor 97/PUU-XIV/2016 agama ditafsirkan tidak terbatas pada agama saja, tetapi juga kepercayaan merupakan penafsiran inklusif yang mengakui keanekaragaman. ${ }^{23}$

Perkawinan yang dilakukan oleh Penghayat Kepercayaan atau perkawinan adat dapat menjadi sah, bila memenuhi syarat yang diatur pada Peraturan Pemerintah Nomor 37 Tahun 2007, bahwa perkawinan harus dilakukan di hadapan Pemuka Penghayat Kepercayaan. Pemuka Penghayat Kepercayaan tersebut telah ditunjuk dan ditetapkan oleh organisasi Penghayat Kepercayaan dan kemudian didaftar pada Kementerian Pendidikan dan Kebudayaan, hal ini sesuai dengan Pasal 81 PP Nomor 37 Tahun 2007.

Keabsahan perkawinan Penghayat Kepercayaan pasca disahkan Putusan Mahkamah Konstitusi Nomor 97/PUU-XIV/2016 membawa akibat hukum bagi pihak yang bersangkutan yaitu suami istri dan anak keturunan yang lahir pada perkawinan tersebut.

Pencatatan perkawinan yang dilakukan oleh Penghayat Kepercayaan membawa dampak pada status anak yang dilahirkan dalam perkawinan tersebut. Pada pokoknya, dengan adanya akta perkawinan, maka seseorang dapat memperoleh akta kelahiran bagi anak-anak sebagai buah perkawinan dan juga pada pembuatan Kartu Keluarga. ${ }^{24}$ Pasca Mahkamah Konstitusi Nomor 97/ PUU-XIV/2016 yang dalam ruang lingkupnya membawa kepastian hukum pada perkawinan Penghayat Kepercayaan, merubah status hukum pula pada anak yang dilahirkan dalam perkawinan tersebut. Anak Penghayat Kepercayaan yang sebelum adanya Putusan Mahkamah Konstitusi Nomor 97/PUU-XIV/2016 tidak dianggap menjadi anak sah menurut UU Perkawinan, sekarang telah mendapat pengakuan secara utuh. Kedudukan anak yang lahir dari perkawinan Penghayat Kepercayaan, sebelum adanya Putusan Mahkamah Konstitusi Nomor 97/PUUXIV/2016 hanya mempunyai hubungan perdata dengan ibunya dan keluarga

${ }^{23}$ ibid.

${ }^{24}$ Ida Ayu Engellika Putri Maya Sadhwi dan I Nyoman Suyatna, 'Kedudukan Perdata Penghayat Kepercayaan Tradisional melalui Penetapan Putusan MK No. 97/PUU-XIV/2018' (2020) 8 Jurnal Kertha Negara.[17]. 
ibunya sesuai dengan Pasal 43 UU Perkawinan, karena perkawinan yang dilakukan secara Penghayat Kepercayaan tidak diperbolehkan oleh negara. Namun pasca terbitnya Putusan MK tersebut, kedudukan anak berubah menjadi anak yang sah. Anak yang lahir dari perkawinan Penghayat Kepercayaan dapat memiliki akta kelahiran yang syarat-syaratnya tertuang dalam Pasal 52 Peraturan Presiden Nomor 25 Tahun 2008 Tentang Persyaratan dan Tata Cara Pendaftaran Penduduk dan Pencatatan Sipil.

Akta kelahiran yang dimiliki oleh anak Penghayat Kepercayaan akan membawa dampak yang luar biasa pada kehidupannya di masa mendatang. Pada bidang pendidikan, anak Penghayat Kepercayaan dapat menempuh pendidikan agama sesuai dengan ajaran yang dianut oleh kedua orang tua nya, yaitu Penghayat Kepercayaan. Hal ini diatur pada Peraturan Menteri Pendidikan dan Kebudayaan Republik Indonesia Nomor 27 Tahun 2016 tentang Layanan Pendidikan Kepercayaan Terhadap Tuhan Yang Maha Esa. Dalam Pasal 1 ayat 3 menyebutkan definisi dari peserta didik Penghayat Kepercayaan yang selanjutnya disebut Peserta Didik adalah peserta didik pada pendidikan formal jenjang pendidikan dasar dan menengah dan pendidikan kesetaraan yang menyatakan dirinya sebagai Penghayat Kepercayaan Terhadap Tuhan Yang Maha Esa.

Akibat hukum lainnya pasca Putusan Mahkamah Konstitusi Nomor 97/ PUU-XIV/2016 terkait perkawinan Penghayat Kepercayaan adalah permasalahan harta bersama dan permasalahan waris. Masyarakat Penghayat yang telah meninggal dunia akan menimbulkan permasalahan hukum terkait harta benda yang ditinggalkan nya, dengan perkawinan yang sah maka akan jelas siapa saja ahli waris dari pewaris yang meninggal tersebut.

Akibat hukum dari perkawinan Penghayat Kepercayaan pasca Putusan Mahkamah Konstitusi Nomor 97/PUU-XIV/2016 telah dijelaskan diatas, terlihat sederhana tetapi membawa dampak yang sangat besar bagi kehidupan masyarakat Penghayat Kepercayaan. Putusan MK tidak hanya menjelaskan dan memutus tentang perluasan makna 'agama' dalam peraturan perundang-undangan, namun juga membenahi sistem administrasi kependudukan di Indonesia terkait 
pendataan Penghayat Kepercayaan. Putusan MK ini juga merupakan upaya negara dalam memberikan perlindungan hukum bagi seluruh rakyatnya tanpa terkecuali, menciptakan keadilan secara sejajar antara Penghayat Kepercayaan dan pemeluk Agama atas dasar kemanusiaan dan menghilangkan diskriminasi atas dasar perbedaan keyakinan terhadap Tuhan YME.

\section{Kesimpulan}

Eksistensi Penghayat Kepercayaan telah diakui oleh negara secara de jure dan de facto, salah satunya adalah pengakuan hukum pasca terbitnya Putusan Mahkamah Konstitusi Nomor 97/PUU-XIV/2016, yang memutuskan bahwa kata 'agama' dalam Pasal 61 ayat (1) dan Pasal 64 ayat (1) Undang-Undang Adminduk bertentangan dengan UUD NRI 1945, dan tidak memiliki kekuatan hukum mengikat secara bersyarat sepanjang tidak termasuk 'kepercayaan'. Putusan MK ini memberi ruang bagi Penghayat Kepercayaan karena definisi 'agama' pada pasal tersebut tidak terikat pada 6 agama resmi saja, tetapi Kepercayaan terhadap Tuhan Yang Maha Esa juga masuk kedalamnya. Perkawinan yang diatur dalam UU Perkawinan harus sesuai dan tidak boleh bertentangan dengan UUD NRI 1945 Pasal 28B ayat (1) bahwa setiap orang mempunyai hak atas perkawinan yang sah tanpa ada diskriminasi atas dasar apapun. Kalimat 'perkawinan yang sah' yang diatur pada Pasal 2 ayat (1) UU Perkawinan yang mewajibkan bahwa perkawinan yang sah harus didasarkan pada agama dan kepercayaannya itu. Makna 'agama' dalam pasal tersebut harus tunduk dan mengikuti Putusan MK Nomor 97/PUU-XIV/2016. Maka dari itu, pencatatan perkawinan yang dilakukan secara Kepercayaan terhadap Tuhan Yang Maha Esa adalah sah dan legal di mata hukum. Namun UU Perkawinan sebagai peraturan khusus yang mengatur tentang perkawinan belum merubah dan memperbaharui peraturan sesuai dengan Putusan Mahkamah Konstitusi Nomor 97/PUU-XIV/2016. Perubahan Undang-Undang Perkawinan bertujuan agar perkawinan Penghayat Kepercayaan tidak hanya sah untuk dicatatkan namun juga sah menurut Undang-Undang Perkawinan. 
Perkawinan yang dilakukan oleh Penghayat Kepercayaan membawa dampak akibat hukum sebelum dan sesudah adanya Putusan MK Nomor 97/ PUU-XIV/2016. Perbedaan tersebut nampak sangat berbeda, karena akibat hukum bukan hanya dirasakan oleh pasangan Penghayat Kepercayaan yang melakukan perkawinan, tetapi juga berdampak pada anak turunannya. Pasca terbitnya Putusan MK Nomor 97/PUU-XIV / 2016, perkawinan Penghayat Kepercayaan diakui sebagai perkawinan yang sah dan membawa akibat hukum yang baik bagi anak turunnya. Pasca terbitnya Putusan MK tersebut, kedudukan anak berubah menjadi anak yang sah. Anak yang lahir dari perkawinan Penghayat Kepercayaan dapat memiliki akta kelahiran yang syarat-syaratnya tertuang dalam Pasal 52 Peraturan Presiden Nomor 25 Tahun 2008 Tentang Persyaratan dan Tata Cara Pendaftaran Penduduk dan Pencatatan Sipil. Selain itu, pasca terbitnya Putusan MK, permasalahan hukum terkait dengan pewarisan akan menjadi jelas yakni dengan perkawinan yang sah maka akan jelas siapa saja ahli waris dari yang meninggal tersebut.

\section{Daftar Bacaan}

\section{Buku}

Eman Suparman, Intisari Hukum Waris Indonesia (Armico 1985).

IGN Nurdjana, Hukum dan Aliran Kepercayaan Menyimpang di Indonesia: Peran Polisi, Bakorpakem dan Pola Penanggulangan (Pustaka Pelajar 2009).

Johny Ibrahim, Teori \& Metodologi Penelitian Hukum Normatif (Bayumedia 2012).

Sirman Dahwal, Perbandingan Hukum Perkawinan (Mandar Maju 2017).

Siti Malikhatun Badriyah, Sistem Penemuan Hukum dalam Masyarakat Prismatik (Sinar Grafika 2016).

Winda Wijayanti, Penghayat Kepercayaan Perlindungan Hukum melalui Hukum Administrasi (Rajawali Pers 2019).

\section{Jurnal}

Aan Andrianih, 'Perlindungan Negara Terhadap Keyakinan Beragama bagi Masyarakat Hukum Adat Terkait Permasalahan Kolom Agama pada 
Dokumen Kependudukan' (2009) Jurnal Rechtvinding.

Herni Widanarti dan Rinitami Njatrijani, 'Implementasi Putusan MK No. 97/ PUU-XIV/2016 terhadap Pelaksanaan Perkawinan pada Masyarakat Adat Samin (Sedulur Sikep) di Jawa Tengah' (2019) Journal Undip 4.

Heru Susetyo, 'Pencatatan Perkawinan bagi Golongan Penghayat' (2017) Jurnal Hukum dan Pembangunan 28.

Ida Ayu Engellika Putri Maya Sadhwi dan I Nyoman Suyatna, 'Kedudukan Perdata Penghayat Kepercayaan Tradisional melalui Penetapan Putusan MK No. 97/PUU-XIV/2018' (2020) Jurnal Kertha Negara 8.

Rizky Sabilatus Safina dan Fauzul Aliwarman,' Akibat Hukum Perkawinan Penghayat Kepercayaan di Indonesia' (2020), Prohutek Prosiding Seminar Nasional Hukum dan Teknologi 1.

\section{Laman}

Hani Adhani, 'Penghayat Kepercayaan Didiskriminasi?' (Antara News, 2018) <https://kl.antaranews.com/berita/3431/penghayat-kepercayaandidiskriminasi> diakses pada tanggal 10 Februari 2020.

Mahkamah Konstitusi Republik Indonesia, 'Majalah Konstitusi: Elemen Data Kependudukan Penghayat Kepercayaan' (Sekretariat Jenderal dan Kepaniteraan Mahkamah Konstitusi, 2017), < https:/ /www.mkri.id/public/ content/infoumum/majalahkonstitusi/pdf/Majalah_133_1.\%20Edisi\%20 November\%202017\%20.pdf> diakses pada tanggal 21 Februari 2020.

\section{Perundang-undangan}

Undang-Undang Dasar Negara Republik Indonesia Tahun 1945.

Ketetapan Majelis Permusyawaratan Rakyat Nomor IV/MPR/1973 tentang GarisGaris Besar Haluan Negara.

Undang-Undang Nomor 1 Tahun 1965 tentang Pencegahan Penyalahgunaan dan Penodaan Agama (Lembaran Negara Republik Indonesia Tahun 1965 Nomor 3).

Undang-Undang Nomor 1 Tahun 1974 tentang Perkawinan (Lembaran Negara Republik Indonesia Tahun 1974 Nomor 1).

Undang-Undang Nomor 39 Tahun 1999 Tentang Hak Asasi Manusia (Lembaran Negara Republik Indonesia Tahun 1999 Nomor 165). 
Undang-Undang Nomor 23 Tahun 2006 tentang Administrasi Kependudukan (Lembaran Negara Republik Indonesia Tahun 2006 Nomor 124).

Undang-Undang Nomor 24 Tahun 2013 tentang Perubahan atas Undang-Undang Nomor 23 Tahun 2006 tentang Administrasi Kependudukan (Lembaran Negara Republik Indonesia Tahun 2013 Nomor 232).

Peraturan Pemerintah Nomor 9 Tahun 1975 tentang Pelaksanaan Undang-Undang Perkawinan (Lembaran Negara Republik Indonesia Tahun 1975 Nomor 12).

Peraturan Pemerintah Nomor 37 Tahun 2007 tentang Pelaksanaan UndangUndang Nomor 23 Tahun 2006 tentang Administrasi Kependudukan (Lembaran Negara Republik Indonesia Tahun 2007 Nomor 80).

Peraturan Pemerintah Nomor 40 Tahun 2019 tentang Pelaksanaan UndangUndang Nomor 23 Tahun 2006 tentang Administrasi Kependudukan sebagaimana telah diubah dengan Undang-Undang Nomor 24 Tahun 2013 tentang Perubahan atas Undang-Undang Nomor 23 Tahun 2006 tentang Administrasi Kependudukan (Lembaran Negara Republik Indonesia Tahun 2019 Nomor 102).

How to cite: Safirah Oktavihana dan Nindia Putri Prameswari, 'Keabsahan dan Akibat Hukum Perkawinan Penghayat Kepercayaan Pasca Terbitnya Putusan Mahkamah Konstitusi Nomor 97/PUU-XIV/2016' (2021) Vol. 4 No. 3 Notaire. 
466 Safirah Oktavihana: Keabsahan dan Akibat Hukum...

--Halaman ini sengaja dikosongkan-- 